SHORT REPORT

\title{
A dystonic syndrome associated with anti-basal ganglia antibodies
}

\author{
M J Edwards, R C Dale, A J Church, G Giovannoni, K P Bhatia
}

J Neurol Neurosurg Psychiatry 2004;75:914-916. doi: 10.1136/jnnp.2002.009043

\begin{abstract}
Anti-basal ganglia antibodies (ABGA) have been associated with movement disorders (usually tics and chorea) and psychiatric disturbance in children. This report describes five adult and adolescent patients (one male, four females; mean age of onset, 16 years (range, 13-35)) who presented subacutely with a clinical syndrome dominated by dystonia and had $A B G A$ binding to antigens of similar molecular weights to those seen in Sydenham's chorea. Three patients had a clear history of respiratory infection before the onset of their symptoms. Three patients received immunosuppressive treatment, with three showing a notable reduction in symptoms. It is hypothesised that dystonia in adults or adolescents may be part of the clinical spectrum of the postinfectious syndrome associated with $A B G A$.
\end{abstract}

A nti-basal ganglia antibodies (ABGA) have been found in association with both Sydenham's chorea (SC), ${ }^{1}$ and a condition in children characterised by a movement disorder (tics and chorea most commonly) and psychiatric problems following streptococcal infection, known as paediatric autoimmune neuropsychiatric disorder associated with streptococcal infection (PANDAS). ${ }^{2}$ A proportion of patients with a diagnosis of Tourette's syndrome (TS) have also been found to have ABGA, and it is possible that PANDAS and TS have considerable overlap, ${ }^{3}$ although this remains controversial. Group A $\beta$ haemolytic streptococcus is thought to be the causative organism involved in SC and PANDAS, and ABGA in SC are crossreactive with antigen extracts of streptococcus. ${ }^{4}$ The pathophysiological mechanism is thought to be autoimmune targeting of the basal ganglia via molecular mimicry, triggered by streptococcal infection. ${ }^{4}$ There have been no previous reports of a dystonic syndrome in adults or adolescents associated with ABGA.

We present the details of five individuals who presented in adolescence or adulthood with a progressive dystonic syndrome. All patients had positive ABGA.

\section{PATIENTS AND METHODS}

These cases were identified during an ongoing study examining the prevalence of ABGA in healthy adults and those with neurological disease. We found ABGA to be rare in these groups of individuals (table 1), but were surprised to find a small number of patients with dystonia who were positive, and who had worsening or onset of symptoms after upper respiratory tract infection and psychiatric disturbance. The clinical notes of these patients were examined, and their case histories are presented below. Table 2 presents summary clinical details of all cases, with full case histories of cases 1 and 2 presented in the text. All cases were investigated extensively for other causes of their movement disorder. Table 3 shows the results for ABGA enzyme linked immunosorbent assay (ELISA), western immunoblotting, and anti-streptolysin O titres (ASOT) for these cases.

\section{ASSESSMENT OF ABGA}

Methods for the assessment of ABGA have been described in detail elsewhere. ${ }^{5}$ Using these methods, western immunoblotting has a sensitivity of $100 \%$ in acute SC and $69 \%$ in persistent (chronic) SC..$^{5}$ In contrast, positive ABGA western immunoblotting is found in only $0-8 \%$ of childhood healthy, neurological, and streptococcal controls. ${ }^{5}$ Although ELISA can be used as a screening assay, the serum antibody titre provides no information on the amounts of ABGA within the central nervous system, and neither is it an indicator of the affinity of the antibodies. Western blotting and immunofluorescence microscopy are the definitive tests for determining the presence of these antibodies. Basal ganglia autoantigens of 40,45 , and $60 \mathrm{kDa}$ are most frequently identified in SC. ${ }^{5}$

\section{CASE SUMMARIES \\ Case 1}

This 13 year old boy developed a sore throat for which he received penicillin, and seemed to recover. Two weeks later, he rapidly deteriorated, with respiratory failure requiring ventilatory support for four days. He swiftly improved, however, allowing him to be discharged home a month later with no apparent neurological abnormalities.

Three weeks later, he developed a gradually progressive dystonia, starting with abnormal posturing of his hands, spreading over six months to clear dystonia of all four limbs, the neck, and bulbar muscles. In addition, there was mild bradykinesia and gait imbalance. He required percutaneous gastrostomy insertion and was aphonic.

Extensive investigations for secondary dystonia including brain magnetic resonance imaging (MRI), electroencephalogram, and blood tests including copper and caeruloplasmin, lactate, pyruvate, amino acid, and organic acid screen were normal. He did not have the DYTl gene abnormality. He received steroids at $1 \mathrm{mg} / \mathrm{kg}$ for six weeks with no obvious response.

\section{Case 2}

This 57 year old woman had a history of a polio-like illness as a child presenting as generalised weakness with full recovery after two years. Unfortunately, no further history is available regarding this illness. In her mid-thirties, with no obvious precipitant, she developed dystonic posturing of the left, and to a lesser extent, the right leg, with stiffness over the period of a few months. Six months later, she developed a postural

\footnotetext{
Abbreviations: $A B G A$, anti-basal ganglia antibodies; ELISA, enzyme linked immunosorbent assay; ivlg, intravenous immunoglobulin; MRI, magnetic resonance imaging; PANDAS, paediatric autoimmune neuropsychiatric disorder associated with streptococcal infection; SC, Sydenham's chorea; TS, Tourette's syndrome
} 
Table 1 Adult control data

\begin{tabular}{|c|c|c|c|}
\hline Control group & $\begin{array}{l}\text { Mean (range) ASOT } \\
\mathrm{IU} / \mathrm{ml}\end{array}$ & $\begin{array}{l}\text { ABGA ELISA (mean, } \\
95 \% \mathrm{CI} \text { ) }\end{array}$ & $\begin{array}{l}\text { Percentage of controls } \\
\text { ABGA positive (antigen) }\end{array}$ \\
\hline $\begin{array}{l}\text { Healthy adults }(n=50) \\
\text { Neurology adults }(n=50)^{*} \\
\text { Movement disorder adults }(n=23) \dagger\end{array}$ & $\begin{array}{l}122(50-376) \\
140(50-1210) \\
194(50-352)\end{array}$ & $\begin{array}{l}0.28(0.26 \text { to } 0.30) \\
0.22(0.19 \text { to } 0.25) \\
0.30(0.27 \text { to } 0.33)\end{array}$ & $\begin{array}{l}2 \%(55 \mathrm{kDa}) \\
0 \\
8 \%(36,40 \mathrm{kDa})\end{array}$ \\
\hline \multicolumn{4}{|c|}{$\begin{array}{l}\text { *This group includes patients with multiple sclerosis }(n=12) \text {, dementia }(n=7) \text {, paraneoplastic syndromes }(n=3) \text {, } \\
\text { autoimmune neuropathy }(n=3) \text {, acute cerebellitis }(n=3) \text {, and other mixed neurological diseases }(n=22) \text {. †This } \\
\text { group includes patients with blepharospasm }(n=10) \text {, DYT1 dystonia }(n=8) \text {, idiopathic Parkinson's disease }(n=4) \text {, } \\
\text { and Huntington's disease ( } n=1) \text {. } \\
\text { ASOT, anti-streptolysin O titres; ABGA, anti-basal ganglia antibodies; Cl, confidence interval; ELISA, enzyme } \\
\text { linked immunosorbent assay. }\end{array}$} \\
\hline
\end{tabular}

tremor of both arms and also torticollis. She was wheelchair dependent as a result of the dystonia affecting her legs. Her dystonic symptoms fluctuated, with relapses and remissions in response to intercurrent infection. Fluctuating anxiety and depression were also prominent symptoms.

Extensive investigations including MRI of the brain and spine, electromyogram, and nerve conduction studies, blood tests including copper studies and anti-glutamic acid decarboxylase antibodies were normal.

For the past two years, she has been treated with intravenous immunoglobulin (ivIg) with a documented $50 \%$ improvement in her dystonia, so that from being wheelchair dependent, she is now able to walk with assistance. During periods of improvement in her dystonia, her psychiatric symptoms also show some improvement. The benefit from each course of ivIg lasts six months.

\section{DISCUSSION}

We have presented the clinical details of five patients who presented with a dystonic syndrome. The additional clinical features of these cases-bulbar involvement (cases 1, 3-5), involvement of the legs in adult onset dystonia (case 2), relatively fixed posturing (cases $2-5$ ), rapid progression (case 1), and precipitating cause (cases 1, 3, 5) —suggested a secondary rather than a primary (idiopathic) dystonia. It was interesting to note in these cases the temporal relation between respiratory infection and the onset or exacerbation of their symptoms. We noted, in retrospect, that apart from dystonia, there were psychiatric problems evident in four of our patients, including non-epileptic (pseudo) seizures (cases 3-5), anxiety (cases 2-5), and depression (cases 2 and 5). Indeed, two of these patients (cases 3 and 4) were referred with a presumed diagnosis of a functional disorder. All these patients were positive for ABGA that bind to basal ganglia autoantigens of the same molecular weight as those seen in SC. Three of them have shown a reduction in their symptoms with immunomodulatory treatment.
What is the relevance or meaning of the ABGA in these cases? One possibility is that the positive ABGA are just an incidental finding in these patients, that the physical symptoms are psychologically mediated, and the immunomodulatory treatments simply provide a psychologically and socially acceptable route for patients to shed their symptoms. However, we found that ABGA are extremely rare in the large population of healthy and neurologically diseased adults that we have studied (table 1). So far, none of our cases of adult onset primary dystonia ${ }^{6}$ or young onset DYTl gene positive dystonia have been found to be positive for ABGA (table 1). In addition, the coincidence of a movement disorder and psychological disturbance in our cases fits well with clinical studies of patients with PANDAS $^{7}$ and $\mathrm{SC}^{8}$ in whom psychiatric disturbance is a frequent finding. Therefore, it is possible that our cases are examples of a dystonic syndrome secondary to an underlying autoimmune process affecting the basal ganglia/central nervous system.

Both animal and human studies have suggested that ABGA may be pathogenic. In rats, the intrastriatal infusion of sera from patients with TS can induce symptoms analogous to those seen in TS. ${ }^{9}{ }^{10}$ A controlled trial of treatment with plasma exchange or ivIg in children with infection triggered exacerbations of obsessive compulsive disorder or tic disorders found a significant improvement in motor and psychiatric symptoms for both treatments compared with placebo. ${ }^{11}$ Although the pragmatic treatment of four of our patients with immunosuppression was successful in three, we acknowledge that such unblinded treatment does not provide firm evidence for the use of such treatments on other patients with ABGA and movement disorders at the present time. However, a formal controlled trial of such treatment in these patients is warranted given our findings.

In conclusion, we suggest that the patients presented here may represent an extension of the spectrum of disorders associated with ABGA to include a dystonic syndrome in adulthood or adolescence. Some of these patients also had psychological disturbances, which may be part of the

Table 2 Clinical details of cases

\begin{tabular}{|c|c|c|c|c|c|}
\hline $\begin{array}{l}\text { Case no; } \\
\text { age; sex }\end{array}$ & $\begin{array}{l}\text { Age at } \\
\text { onset }\end{array}$ & $\begin{array}{l}\text { Precipitating } \\
\text { factor at onset }\end{array}$ & Distribution of dystonia & Other features & Response to immunosuppressive treatment \\
\hline $\begin{array}{l}1 ; 17 \text { years; } \\
\text { male }\end{array}$ & 13 & $\begin{array}{l}\text { Streptococcal } \\
\text { septicaemia }\end{array}$ & $\begin{array}{l}\text { Generalised with bulbar } \\
\text { involvement }\end{array}$ & Mild bradykinesia & No response to oral prednisolone \\
\hline $\begin{array}{l}\text { 2; } 57 \text { years; } \\
\text { female }\end{array}$ & 35 & None & $\begin{array}{l}\text { Generalised, with prominent } \\
\text { dystonic tremor in arms }\end{array}$ & Anxiety and depression & $\begin{array}{l}\text { Clear response to intravenous immunoglobulin, with } \\
\text { effect lasting 5-6 months }\end{array}$ \\
\hline $\begin{array}{l}3 ; 31 \text { years; } \\
\text { female }\end{array}$ & 16 & $\begin{array}{l}\text { Upper respiratory } \\
\text { tract infection }\end{array}$ & $\begin{array}{l}\text { Generalised; fixed dystonia } \\
\text { in right foot and hip }\end{array}$ & $\begin{array}{l}\text { Non-epileptic (pseudo) } \\
\text { seizures, anxiety }\end{array}$ & $\begin{array}{l}\text { Significant clinical improvement with steroid } \\
\text { treatment, relapse following steroid withdrawal, and } \\
\text { further improvement after azathioprine }\end{array}$ \\
\hline $\begin{array}{l}4 ; 28 \text { years; } \\
\text { female }\end{array}$ & 15 & None & $\begin{array}{l}\text { Generalised with bulbar } \\
\text { involvement }\end{array}$ & $\begin{array}{l}\text { Non-epileptic (pseudo) } \\
\text { seizures, anxiety }\end{array}$ & $\begin{array}{l}\text { Significant clinical improvement with steroid } \\
\text { treatment, relapse following steroid withdrawal }\end{array}$ \\
\hline $\begin{array}{l}5 ; 26 \text { years; } \\
\text { female }\end{array}$ & 15 & $\begin{array}{l}\text { Upper respiratory } \\
\text { tract infection }\end{array}$ & $\begin{array}{l}\text { Generalised with bulbar } \\
\text { involvement }\end{array}$ & $\begin{array}{l}\text { Non-epileptic (pseudo) } \\
\text { seizures, anxiety, depression }\end{array}$ & Not attempted \\
\hline
\end{tabular}


Table 3 Serology results from cases

\begin{tabular}{lllll}
\hline Case & Serology & ASOT & ABGA ELISA & $\begin{array}{l}\text { ABGA western } \\
\text { blotting }(\mathrm{kDa})\end{array}$ \\
\hline 1 & Acute & 3150 & 0.62 & 60,98 \\
2 & Chronic & 400 & 1.49 & 45,60 \\
3 & Relapse & 118 & 0.56 & 40,60 \\
4 & Chronic & 139 & 0.58 & 40,95 \\
5 & Chronic & 213 & 0.46 & 60 \\
\hline
\end{tabular}

Normal range for ASOT: $<200 \mathrm{IU} / \mathrm{ml}$ (World Health Organisation reference range); normal range for $\mathrm{ABGA}$ ELISA: $<0.44$ absorbance units in adults.

ASOT, anti-streptolysin $O$ titres; $A B G A$, anti-basal ganglia antibodies; $\mathrm{Cl}$, confidence interval; ELISA, enzyme linked immunosorbent assay.

disorder. Whether ABGA are simply an epiphenomenon or have functional effects on the basal ganglia awaits further in vitro and in vivo studies. If these antibodies are indeed pathogenic, then future research would need to ascertain the prevalence of ABGA in patients with neurological diseases and the role of immunomodulation in their treatment.

\section{Authors' affiliations}

M J Edwards, K P Bhatia, Sobell Department of Movement Neuroscience and Movement Disorders, Institute of Neurology, University College London, Queen Square, London WCIN 3BG, UK

R C Dale, A J Church, G Giovannoni, Neuroimmunology Unit, Department of Neuroinflammation, Institute of Neurology, University College London

R C Dale, Neurosciences Unit, Institute of Child Health, Guilford Street, London WCIN 3JJ, UK

Competing interests: none declared
Correspondence to: Dr K Bhatia, Sobell Department of Motor Neuroscience and Movement Disorders, Institute of Neurology, Queen Square, London WCIN 3BG, UK; k.bhatia@ion.ucl.ac.uk

Received 20 December 2002

In revised form 28 April 2003

Accepted 24 May 2003

\section{REFERENCES}

1 Husby G, van de Rijn I, Zabriskie JB, et al. Antibodies reacting with cytoplasm of subthalamic and caudate nuclei neurons in chorea and acute rheumatic fever. J Exp Med 1976;144:1094-110.

2 Kiessling LS, Marcotte AC, Culpepper L. Antineuronal antibodies in movement disorders. Pediatrics 1993;92:39-43.

3 Leonard HL, Swedo SE. Paediatric autoimmune neuropsychiatric disorders associated with streptococcal infection (PANDAS). Int J Neuropsychopharmacol 2001;4:191-8

4 Bronze MS, Dale JB. Epitopes of streptococcal M proteins that evoke antibodies that cross-react with human brain. J Immunol 1993;151:2820-8.

5 Church AJ, Cardoso F, Dale RC, et al. Anti-basal ganglia antibodies in acute and persistent Sydenham's chorea. Neurology 2002;59:227-31.

6 Ramachandran V, Church A, Giovannoni G, et al. Anti-basal ganglia antibodies are absent in patients with primary blepharospasm. Neurology 2002;58:150.

7 Leonard HL, Swedo SE. Paediatric autoimmune neuropsychiatric disorder associated with streptococcal infection (PANDAS). Int J Neuropsychopharmacol 2001:4191-8

8 Moore DP. Neuropsychiatric aspects of Sydenham's chorea: a comprehensive review. J Clin Psychiatry 57:407-14.

9 Hallett JJ, Harling-Berg CJ, Knopf PM, et al. Anti-striatal antibodies in Tourette syndrome cause neuronal dysfunction. I Neuroimmunol 2000;111:195-202.

10 Taylor JR, Morshed SA, Parveen S, et al. An animal model of Tourette's syndrome. Am J Psychiatry 2002;159:657-60.

11 Perlmutter SJ, Leitman SF, Garvey MA, et al. Therapeutic plasma exchange and intravenous immunoglobulin for obsessive-compulsive disorder and tic disorders in childhood. Lancet 1999;354:1153-8. 